Marnie Hay, 'Scouting for rebels: Na Fianna Éireann and preparation for the coming war, 1909-1918' in Lissa Paul, Rosemary Ross Johnston, and Emma Short (eds), Children's Literature and Culture of the First World War (New York and London: Routledge, 2016), pp 268-82.

\title{
Scouting for Rebels: Na Fianna Éireann and Preparation for the Coming War, 1909-1918
}

\author{
Marnie Hay
}

Ireland, like other European countries, witnessed the rise of 'pseudo-military' youth groups in the late nineteenth and early twentieth centuries. These organizations were not only a manifestation of the cult of discipline, training and manliness that grew out of the anxiety about the coming war, but also, perhaps, a reaction to a widely perceived fin-de-siècle 'decadence' (Fitzpatrick, 1996: 382-3). In the early years of the twentieth century, many Germans worried that 'middle-class boys were effeminate' and 'the country lacked virile soldiers' (Donson, 2010: 49). Similarly, the British army's poor performance against a force of South African farmers during the Boer War (1899-1902) had provoked much concern that Britain was in a state of decline. Fearing that they were losing their competitive edge in industrial and military affairs and that their populations were deteriorating both physically and morally, western countries like Germany and Britain began to concern themselves with the health, education and moral welfare of the new generation (Heywood, 2005: 29-30). The establishment of uniformed youth groups was one way of dealing with the perceived problem.

The best known of these youth groups was the international Boy Scout movement founded by Robert Baden-Powell in 1908. A British army officer who specialized in reconnaissance and scouting, Baden-Powell started this movement in response to the interest that boys had shown in his 1899 army training manual, Aids to Scouting. He was also inspired by the model of the Boys' Brigade, which was launched by William Alexander 
Smith in 1883 in Glasgow (Smith, 1997b: 119). Smith was a businessman and an officer in the Volunteers, a British part-time military force that was later replaced by the Territorial Army (Springhall, 1986: 39). He used military drill and discipline as a way of providing guidance to the boys who attended his Scottish Free Church Sunday School (Smith, 1997a: 119). Smith's example also inspired the formation of the Church Lads' Brigade for Anglicans and the Jewish Lads' Brigade. Baden-Powell, in contrast, put less overt emphasis on militarism. Instead he focused on outdoor activities and personal development in order not only to train boys to be better citizens, but to counter what he saw as the moral and physical decline of the upcoming generation (Smith, 1997b: 119). [p. 268]

The impetus for the outdoor element of scouting came from the American-based naturalist Ernest Thompson Seton and his Woodcraft movement, which promoted outdoor life and the lore of Native American tribes. Baden-Powell and Seton met in 1906, sharing their respective ideas on youth groups. Seton co-founded the Boy Scouts of America, subsuming his own Woodcraft movement into the new group; however, he objected to the Scout movement's emphasis on patriotism and was forced out of the American organization in 1915 (Morris, 1970: 185, 187-8). Whether Baden-Powell's main concern prior to 1920 was training future citizens or soldiers has sparked much scholarly debate (see, for example, Warren, 1986 and Springhall, 1987). Tensions within the early Scout movement, as exemplified by Seton and others, suggest that Baden-Powell initially sought to train both.

The Boy Scout movement quickly spread to Ireland, with troops in existence in the Dublin area and Belfast from early 1908. Members of the Anglo-Irish aristocracy, such as the twelfth Earl of Meath, supported the new youth movement from the beginning, often providing leadership and camping facilities on their estates (Gaughan, 2006: 5-8). Not everyone in Ireland greeted this new British cultural import with such open arms, especially at a time when nationalists were actively engaged in combating cultural assimilation through 
the revival of aspects of traditional Irish culture, such as the Irish language. Some Irish nationalists, however, could see the value of Baden-Powell's vision of training youth for their future roles as citizens and soldiers, but not in the service of Britain and its Empire. This chapter examines the most significant Irish nationalist manifestation of the uniformed 'pseudo-military' youth group, viewing it as an example of children's culture produced by the anticipation and anxieties associated withthe approaching war(s).

\section{The emergence of Irish nationalist youth groups}

Some advanced nationalists viewed British uniformed youth groups as a threat that could be turned into an opportunity. ${ }^{1}$ In 1909 , two protestant Irish nationalist activists, Countess Constance Markievicz (1868-1927) and Bulmer Hobson (1883-1969), founded Na Fianna Éireann (or the Irish National Boy Scouts) in Dublin in order to counteract the growing popularity and influence of the Boy Scout movement and the Boys' Brigade in Ireland. Markievicz and Hobson met in Dublin in 1908. Both had family ties to Britain as well as Ireland: their fathers' families had settled in Ireland during the seventeenth-century plantations and their mothers were English. Aside from that, they were an unlikely pair. In her early forties, Markievicz was married to a Polish count and had been born into the privileged life of the Anglo-Irish Gore-Booth family, who were landowners in Co. Sligo (Paŝeta, 2009). In contrast, Hobson, who was in his mid twenties, was the product of a liberal middle-class north Belfast Quaker family. It was through his mother Mary Ann Bulmer Hobson, a [p. 269] women's rights activist, that he met Alice Milligan and Ethna Carbery (the pseudonym of Anna Johnston), two poets of the Irish literary revival who helped to spark his interest in Irish nationalism. Working in the printing trade, Hobson became an active advanced nationalist propagandist from his late teens onwards (Hay, 2009: 6-7, 11, 14). 
Markievicz was a more recent convert to nationalism, having been inspired by a chance encounter with a stack of advanced nationalist newspapers (Markievicz, 1923: 5).

Markievicz and Hobson were not the only Irish nationalists to recognize the value and appeal of uniformed youth groups in the early twentieth century. For instance, May Kelly and her sister Elizabeth established the Clann na Gael Girl Scouts in Dublin circa 1910-11. ${ }^{2}$ This group catered for girls between the ages of eight and sixteen years, offering its members such activities as camping trips and military training (Matthews, 2010: 109; Ó Ruairc, 2013; McLoughlin, 1954). The Kelly sisters may have been inspired by the foundation of the female equivalent of scouting, the Girl Guides Association, by Agnes Baden-Powell in 1910 and the subsequent formation of Ireland's first official Girl Guide company in Harold's Cross in Dublin in 1911 (Irish Girl Guides, 2009), or perhaps by the establishment of the Fianna. The Clann na Gael Girl Scouts shared a meeting hall with the Hibernian Rifles, which was the militia wing of the Irish-American Alliance. This was the more radical, less sectarian section of the Ancient Order of Hibernians (AOH), a Catholic friendly society that supported home rule for Ireland (Ó Ruairc, 2013). The AOH also established its own youth organization, the Hibernian Boys' Brigade. The Fianna, however, are the best known and most historically significant of these Irish nationalist manifestations of the 'pseudo-military' youth group.

In the British context, the establishment of uniformed youth groups revealed an underlying adult view of youth as a problem that required a solution. Such youth groups were often designed to keep working-class boys off the streets and provide them with a pastime that promoted middle-class values of order and discipline (Springhall, 1986: 27, 64), values that would serve the state well in time of war. Markievicz, however, was less interested in keeping Irish boys off the streets than in keeping them out of the meeting halls of the Boys' Brigade and the Boy Scouts. She and Hobson appear to have harbored a more positive view 
of youth than their British counterparts, seeing boys as a potentially valuable resource for the Irish nationalist movement. Thus, the Fianna were designed to provide members with the military training and nationalist nurturing to enable them to defy future calls to support the British war effort during the First World War, and instead play an important role in the struggle for Irish independence.

Not all Irish nationalists could see the value of the youth group, however. Liam Mellows, who travelled around the country in 1913 trying to organize new Fianna sluaighte (troops), recalled that some of the 'would-be Nationalists' that he 'appealed to for help, spoke of the movement with sarcasm and pointed out how, in their worldly wisdom, it was doomed to [p. 270] failure'. 'What can a handful of boys do against the great British Empire?' some shrugged. Others feared that the Fianna would give the boys a taste for military life that would inspire them to join the British army, despite a pledge taken by Fianna members not to do so. Still others found the youth group's advanced nationalist principles too extreme (Mellows, 1917). In time, the nationalist naysayers were proved both right and wrong. A small minority of Fianna members did choose to serve in the British forces during the First World War. But for the majority of members, the approaching war, for which they were preparing their minds and bodies, was not between Britain and Germany and their respective allies, but between Ireland and Britain. Some Fianna members experienced their first taste of this war during the Easter Rising of April 1916. For others, their experience would not begin until January 1919 with the outbreak of the Irish War of Independence, also known as the Anglo-Irish War (1919-21).

\section{Na Fianna Éireann}

The Fianna were officially established on 16 August 1909 at a meeting chaired by Hobson in a former theatrical hall on Camden Street in Dublin. In its 21 August 1909 edition, An 
Claidheamh Soluis reported that this new national boys' organization would be 'conducted on national non-party lines, and [...] managed by the boys themselves' (10). Estimates suggest that between thirty and one hundred boys from the local neighborhood turned up for this meeting (Lonergan, 1948; Mac Caisin, 1947), which was also attended by Markievicz and several other adults. In his address, Hobson explained that the organization would be run on a semi-military basis along the lines of the Boy Scout movement founded in the previous year by Baden-Powell. In fact, it was one of the immediate objectives of this new group to counteract the influence in Ireland of Baden-Powell's pro-British body (Martin, 1951).

An executive council was elected at this meeting, with Hobson as president and Markievicz as vice-president (Hay, 2008: 57). The election of the countess was controversial. Many boys were reluctant to accept a woman in office because they felt there was no place for a female in a physical-force association (Mac Caisin, 1947). Ironically, she was the bestqualified person in the hall to teach them how to handle firearms (Marreco, 1967: 118). According to Hobson, he often had to point out discreetly that the boys could not take her money and at the same time deny her membership or office. However, 'this feeling against the presence of a woman in a boys' organization continued in varying degrees of intensity for several years' (Hobson, 1968: 16). Markievicz later replaced Hobson as president when he moved back to Belfast for a year during a spell of unemployment.

An Chéad Sluagh, the first Fianna troop, was born out of the inaugural meeting in August 1909. Soon, further troops were formed in Dublin and beyond, though growth tended to be slow and often unsteady. Despite several setbacks due to local politics and limited funding, by 1913 the organization [p. 271] had spread from the Dublin area and Belfast, where Hobson had formed an earlier incarnation of the Fianna in 1902, to such Irish cities and towns as Waterford, Cork, Limerick, Derry, Listowel, Tralee, Tullamore, Enniscorthy and Newry, as well as to Glasgow, where a sizeable Irish community existed (Hay, 2008: 59). 
The Fianna purported to be a national organization open to all Irish boys between the ages of eight and eighteen, no matter 'what class, creed, or party that they or their fathers belong[ed] to' (Ó Riain, 1914: 23). Although the official age limit for Fianna membership was eighteen, some of the officers remained in the organization until their early twenties. The Fianna attracted members from working- and middle-class backgrounds. Unlike other youth groups of the period, such as the various boys' brigades, religion played no official part in the Fianna, probably because its protestant founders not only recognized how politically divisive religion was in Ireland, but also did not want Catholic parents to fear proselytism. As nationalism tended to be associated with Catholicism, the majority of Fianna members came from Catholic families, but protestant and Jewish boys also joined (Hay, 2011: 441-54). Members of the Fianna were products of families with nationalist sentiments of varying degrees, though one mother recalled that 'only the most extreme families had enrolled their sons in the Fianna' (Ceannt, 1949). Occasionally, however, boys joined the Fianna despite parental opposition. For instance, one member's father, a Royal Irish Constabulary pensioner, disapproved of republicanism (White, 2009).

A family commitment to nationalism (of some degree) was often reinforced by the schools or clubs that Fianna boys attended. Many members were educated at Christian Brothers' schools, while a small number went to St Enda's School set up by Patrick Pearse, a leader of the Easter Rising. These schools were notable for their emphasis on providing an overtly Irish education for students, particularly through the teaching of history, geography and the Irish language. Many Fianna members were also involved in cultural nationalist organizations such as the Gaelic League and hurling clubs. Some members had already left school, working as clerks or apprentices to various trades (Hay, 2011: 444). This is not surprising given that in 1911 almost 19 per cent of the total workforce in the United Kingdom consisted of those aged between ten and twenty (Springhall, 1986: 65). 
Some members had belonged to other uniformed youth groups, but shifted their membership to the Fianna because its Irish nationalist orientation was more in keeping with their own sense of identity. For instance, in Glasgow, Séamus Reader had been a member of the Boy Scouts, but left in 1911 after his brother, who was a member of the Fianna, told him the Irish group was better (Reader, 1951). Cork boy scouts Liam O'Callaghan and Christy Moynihan also switched to the Fianna (O'Callaghan, 1947). In Ballybunion, Co. Kerry, the Baden-Powell scouts and the Fianna competed for members when rival troops were established around the same time in 1913 (McCabe, 1955). [p. 272]

Although the Fianna were officially for boys, some girls joined in certain parts of the country for limited periods of time. During 1911-16 there was a girls' troop in Belfast, in which two daughters of Labour leader and 1916 insurrectionist James Connolly played an active role. The question of whether to admit girls nationally was a source of controversy, and a 1912 ard fheis (annual congress) decision to establish girls' troops was quickly reversed. Girls remained involved, even though they had no official representation at the national level (Hay, 2008: 61-2). For instance, in the period 1916-18 girls under the age of eighteen joined the Fianna in Waterford, possibly to avoid the allegedly bossy leader of the local branch of the nationalist women's organization Cumann na mBan (Jacob, 1916). In early 1918, however, Fianna headquarters in Dublin informed the girls that they should join the Clann na Gael Girl Scouts instead (Lane, 2010: 123). When a branch of this girls' group was formed in Cork city in 1917, it served as 'a junior auxiliary' for Cumann na mBan and a female counterpart to the Fianna (Duggan, 1957).

The Fianna offered boys (and some girls) a combination of military training, outdoor pursuits and Irish cultural activities. Inherent in the Fianna's foundation was the recognition that youth were the future of the Irish nationalist movement. Therefore, the organization was designed to provide young people with the education and training necessary to enable them to 
assume their place within that movement. The Fianna undertook this task through a variety of activities, such as weekly meetings, route marches, camping trips and céilís (Irish dancing evenings). The organization also produced and disseminated print propaganda through such vehicles as the 1914 Fianna Handbook and in articles published in advanced nationalist newspapers. Two enterprising members in their late teens, Percy Reynolds and Patsy O'Connor, even produced a one-off Christmas magazine entitled Nodlaig na bhFiann in 1914 and launched a short-lived monthly paper called Fianna in 1915, demonstrating how involvement in the youth group could enable members to gain hands-on experience and build self-confidence.

To move up within the ranks of the Fianna (at least during 'peace time'), members had to pass tests on Irish language and history, as well as on military drill, signaling, first aid and other skills necessary for scouting and camping, such as tent pitching, map reading and topography. Practical instruction on these topics was provided at weekly meetings, on camping trips, and in the handbook and newspaper articles. Opportunities to put these skills to use in real-life situations sometimes arose. For example, during the 1913 Dublin Lockout, Patsy O'Connor administered first aid to labor protesters who had been attacked by police. While helping a wounded worker, he too was beaten with a baton and rendered unconscious (Nelson [Ó Riain], 1915a: 8). Some weekly meetings featured lectures on Irish history, particularly the history of battles and insurrections, in order to give members 'a reason for their own military training' (Martin, 1951). In addition to such lectures, newspaper articles and chapters in the handbook [p. 273] educated members about Irish folklore and history (from an Irish nationalist perspective, of course) in order to teach them about their own unique heritage, to familiarize them with the nationalist vision of Ireland's long struggle against British rule, and to introduce them to Irish heroes worthy of emulation. For instance, Patrick Pearse contributed a chapter to the Fianna Handbook in which he traced the three 
traditions of the Fianna in Ireland - the mythical hero Fionn Mac Cumhaill's Fianna, the nineteenth-century Fenians who rebelled against British rule in Ireland, and the new Fianna boy scout movement - before focusing on the tradition surrounding Fionn's legendary thirdcentury band of warriors (Pearse, 1914: 151-165). Fianna members also learned to govern themselves by being responsible for the running of the organization, preparing them for citizenship, and possibly even leadership, in an independent Ireland. At least ten former Fianna members later became deputies in Dáil Éireann (the Irish legislative assembly), while at least four became senators (Hay, 2011: pp 449, 454).

The Fianna's training program did not appeal to everyone. For instance, James Fulham began attending Fianna meetings in Dublin circa 1912-13 at which he received training in signaling and Morse Code. He later recalled:

As I was very young at the time I didn't take seriously to this form of training and like many of my comrades we began to take less and less interest in the Fianna and finally left it. We didn't realise or appreciate the training that these units were providing for us. (Fulham, 1952)

Fulham only later recognized the value of such training when he joined the Irish Republican Army (IRA) and served during the Irish War of Independence, later becoming a commandant in the Irish Defence Forces (Fulham, 1952). Many boys who remained members of the Fianna followed a similar career path to Fulham.

Instruction in the use of firearms was the most controversial aspect of the Fianna's training program. In Dublin, Markievicz provided such instruction from an early stage. For training purposes, a small Lee Enfield rifle was used outdoors and a large air rifle indoors (Mac Caisin, 1947). The quality of such training is open to question. According to Seán Kennedy, he was placed on guard duty at a weekend Fianna camp at Belcamp Park in north Co. Dublin when he was about fourteen years of age and given a .22 rifle which he did not 
know how to handle (Kennedy, 1953). Not all nationalists, let alone Fianna members, were comfortable with this aspect of military training. For example, Fianna member Thomas O'Donoghue 'objected to boys being trained to use arms'. A future Catholic priest, O’Donoghue left the Fianna in 1912 to help form a breakaway group called the Irish National Guard, explaining that 'our idea was to have youths, not boys, trained in the use of arms' (O’Donoghue, n.d.). He did not define at what age boys became youths. ${ }^{3}$ Writer and nationalist activist Rosamond Jacob also did [p. 274] not 'think boys under 16 ought to be let use arms at all; it can't but be bad for them' (Lane, 2010: 122). Although she recognized the potential value of the Fianna, and became honorary president of a troop of Fianna girls in Waterford, Jacob had concerns about the nature of Markievicz's leadership and its impact on members: 'Madame is a bloodthirsty woman [...] and the [Fianna] boys seem the same in theory. Now if some humane person had charge of the Fianna what a lot of good might be done' (Lane, 2010: 64). Thus, uniformed youth groups did not just instill order, discipline and specific skills in their members; they could also be training grounds for nationalist fundamentalism. In Germany, the years of the First World War saw the expansion of military youth companies. These groups not only 'reinforced the idea that $[\ldots]$ aggressiveness and a willingness to sacrifice life for the nation were positive traits', but also helped to mould future Nazis (Donson, 2006: 353).

Similarly, in addition to their training initiatives, the Fianna endorsed suitable role models for Irish boys, promoting an idealized image of Irish nationalist youth that emphasized the importance of patriotism and morality. According to a copy of the Fianna Code of Honour from 1929 (though developed a decade earlier), a Fianna member was to learn 'all about his country, its history and language, its resources and industries, and his one aim in life [was] to serve it to the best of his ability'; he should also keep his body and mind 'clean and pure'. Members were urged never to 'do anything that would bring discredit upon 
Ireland or upon the Fianna' (Ó Riain, 1914: 14). The Fianna praised qualities that were similar to those promoted by Baden-Powell's Boy Scouts, which included self-discipline, obedience, loyalty, sobriety and cleanliness (Baden-Powell, 1908: 266). Despite these obvious parallels, however, advanced nationalist propaganda from this period highlighted a moral dichotomy between Ireland and Britain, criticizing the alleged 'degenerate and debased nature of British and pro-British people' (Novick, 2001: 169). As part of this idealized image of nationalist youth, Fianna members were to be prepared to make the ultimate sacrifice to attain Irish independence. In the Fianna Handbook, Markievicz predicted that members of the Fianna would not 'flinch' if the 'path to freedom' led to their death (Ó Riain, 1914: 8). Those members who died as a result of their involvement in the Easter Rising or the War of Independence were not only praised in post 1916 Fianna propaganda, but promoted as worthy role models for future generations.

The Fianna's military training program began to prove its value to the advanced nationalist movement when adult paramilitary organizations were formed in Ireland in 1913. The year began with the official establishment of the Unionist Ulster Volunteer Force to oppose the impending implementation of home rule in Ireland. At the behest of Hobson, senior Fianna officers began to drill Dublin members of the Irish Republican Brotherhood (IRB) in the summer, in anticipation of the formation of a nationalist counterblast to the Ulster Volunteers. The IRB was a secret society committed to the [p. 275] establishment of an independent Irish republic through the use of physical force if necessary. In November 1913, when Hobson helped to form the Irish Volunteers, later known as the IRA, he recruited five senior Fianna officers to the provisional committee of the new body. These young men visited various halls in the evenings, instructing the officers and directing the course of training. Not surprisingly, most of these officers were IRB men who had received training from these Fianna members prior to the formation of the Volunteers (Hay, 2008: 62). 
In addition to providing officers and instructors to the new adult body, the Fianna contributed numerous rank-and-file Volunteers. The Fianna introduced a new rule in which members who had reached the age of eighteen but had not achieved the rank of lieutenant were automatically transferred to the Irish Volunteers. The arrangement was deemed a success by both organizations (Martin, 1951). Alternatively, Fianna members loyal to the Labour movement gravitated to the Irish Citizen Army, which had been formed earlier in November 1913 to protect striking workers during the Dublin Lockout (Kavanagh, 1957).

The Fianna may have attracted members from a wider nationalist spectrum after the establishment of the Irish Volunteers because many sons of Volunteers joined the youth group. The adult organization initially included home rulers as well as republicans and Sinn Féiners. The latter were supporters of Arthur Griffith's Sinn Féin [ourselves] Party, which urged the Irish to pursue policies of national self-reliance and passive resistance to British rule. The split in the Irish Volunteers in September 1914 had an impact on membership numbers in the Fianna, both positively and negatively. The split occurred after Irish Parliamentary Party leader John Redmond, without consultation, urged the Volunteers to fight in the First World War, which had broken out the previous month. For Redmond, supporting the war effort was a way of demonstrating that, even under home rule, Ireland would remain a loyal part of the United Kingdom. While a majority followed Redmond under the new name, the National Volunteers, and joined the British army, a more radical minority adhered to the force's original name and aim to defend purely Irish interests.

After the split, Redmond's supporters denounced the Irish Volunteers and the Fianna, particularly for their propagandist campaign against Irish recruitment into the British army. For instance, on 14 November 1914, the Irish Volunteer newspaper reported that the mayor of Kilkenny had urged 'boys not to sign the Fianna declaration' and to secede from the organization, while in Belfast a section of the $\mathrm{AOH}$ pursued similar tactics (16). In the same 
edition of the Irish Volunteer, Fianna secretary Pádraic Ó Riain noted that such publicity attracted 'hundreds of recruits' in places like Dublin, where the Fianna organization was strong (16). On 28 November 1914, the paper boasted that the Dublin Battalion had at least 500 members (15). However, the 13 February 1915 edition reported that Waterford may have 'weathered the storm that [...] wrecked more than one' of the troops around [p. 276] the country, but other places were not so resilient (8). For example, on 12 June 1915, the Irish Volunteer described only three Belfast troops as 'hard at work' (8), while on 13 March 1915 the paper indicated that membership in the Limerick sluagh (troop) was down to sixty boys (8) from a high of 250 as reported in the January 1913 edition of Irish Freedom (6).

It appears that an attempt was made to use the Belfast Fianna as a recruiting ground for the British army after the outbreak of the war. An unnamed Fianna instructor, who had served in the army, approached some of the boys about enlisting. Having given him a noncommittal answer, the boys reported the incident to some senior Fianna members who took action. They eschewed a formal court martial for fear that the instructor might seek outside aid and instead staged a showdown at a forthcoming céilí. According to Ina Heron, one of the few female members of the Fianna and a daughter of James Connolly, they decided:

that at a given hour we would all take part in a sixteen hand reel and when the music was about to stop we would all encircle this instructor and give him a time limit to leave the city and on no circumstance to enter the Fianna premises.

The individual initially refused to consent, demanding a court martial, but faced with the steadfast determination of his former pupils, gave in and disappeared from the Fianna scene (Heron, 1954).

In contrast to this Belfast incident, some Fianna members did choose to serve in the British army during the war, breaking their Fianna pledge not to do so. Among them were 
several older Cork members, including Christy Moynihan, the Cork sluagh's second scoutmaster (or captain) who had previously transferred from the Baden-Powell scouts to the Fianna (O’Shea, n.d.). Another example was Waterford Fianna officer Thomas Barr, who joined the British army upon the outbreak of war (Hearne, 1958). Fianna members who fought during the First World War may have been supporters of home rule, heeding Redmond's call for Irishmen to support the war effort. Perhaps in different circumstances they would not have joined the British army.

The conflicting responses to the war effort demonstrated by individual Fianna members mirrored disputes amongst adults espousing differing degrees of nationalism. For instance, in some areas of Ireland, support for the British war effort had a negative impact on the advanced nationalist movement. 'Encouraged by a recruiting campaign launched by the Irish Parliamentary Party on behalf of the British Army, enemies emerged from everywhere,' recalled Liam Langley, a Fianna leader in Tuam, Co. Galway. 'Pastors, parents, merchants and employers were approached and pressed to withdraw support from the national organizations. Cases were reported where they went even further, a Fianna uniform [...] having been burnt to ashes by the employer of the Fianna boy concerned' (Langley, 1953). [p. 277] Despite such opposition, Ó Riain reported in the 17 April 1915 edition of the Irish Volunteer that the first five years of the Fianna's existence had placed the organization on a sound basis, but that members could not 'afford to go plodding along slowly' as they had previously. Alluding to the possibility that Britain's weakness during the First World War might be Ireland's opportunity, he predicted that 'great changes' in the country's national life were ahead, and advised the Fianna to 'be organised and strong' in order to prevent the movement from 'being submerged by coming crises' (8).

The first of these crises was the Easter Rising, which took place during the week of 24-29 April 1916, mainly in Dublin. Plans for this rebellion, which was masterminded by the 
Military Council of the IRB, were first discussed after the outbreak of the First World War in August 1914. Fearing that Irish people would be satisfied with home rule and not push for an independent republic, the leaders of the IRB were keen to strike before the end of the war when home rule was due to be implemented in Ireland. Although efforts were made to keep younger boys out of action during the rebellion by organizing a camp for the Easter weekend, many former and current members of the Fianna participated in the rising as commanders, fighters, couriers and scouts. According to the Fianna Roll of Honour, seven were killed in action (Holland, circa 1981: 25), including fourteen-year-old dispatch carrier John (aka Seán) Healy (Weekly Irish Times, 1917: 59, 61, 265). Among the sixteen men executed for their roles in the rising were two Fianna leaders in their twenties: Seán Heuston and Con Colbert. Markievicz, who was second-in-command at St Stephen's Green, was spared the same fate by her gender. The executions of Heuston and Colbert served as fuel for future Fianna propaganda, with a 1922 Easter Week Commemoration Aeridheacht Souvenir Programme declaring that they 'met their deaths, happy that it was for Ireland, sure of the heaven that awaited them. In boyish simplicity and purity, and with manly courage, they faced the firing squad' (7). Thus, the involvement of current and former members in the rising was a source of pride for the Fianna and a clear demonstration of the organization's ability to indoctrinate and mobilize nationalist youth.

The Fianna were 'probably the first of the [Irish nationalist] military bodies to gather the threads of its organisation together' after the rebellion. In early May 1916, all of the available officers who had served in the rising and were still at liberty attended a meeting at the Camden Street hall where they decided 'to hold together at least a skeleton organisation' for the time being (McNeill, 1956). As officers were released from prison and troops around the country re-grouped, the Fianna attracted a growing number of members as a result of increasing public support for the advanced nationalist cause sparked by sympathy for the 
executed leaders of the rising and frustration at the still distant prospect of home rule. The organization later boasted that its numbers had soared to an all-time high of 30,000 by June 1917 (Mac Fhloinn, 1988: 14), but police intelligence reports, though flawed, recorded [p. 278] only 359 members outside of Dublin city in that month, suggesting that the Fianna's figure is probably inflated (County Inspectors Confidential Reports, 1917). During this period the Fianna continued their military training program and assisted in the ongoing advanced nationalist campaign against Irish recruitment into the British army. Members also distributed Sinn Féin posters and leaflets during the 1918 general election campaign.

Erroneously associated with the Easter Rising in the public mind, the Sinn Féin Party had slowly overtaken the champions of home rule, the Irish Parliamentary Party, as the most popular political party in Ireland between 1916 and 1918. During the 1918 election campaign, Sinn Féin candidates pledged to abstain from taking seats in the British parliament and instead to establish a separate Irish parliament, which they duly did. Dáil Éireann met for the first time on 21 January 1919, coincidentally the same date that witnessed the opening shots of the Irish War of Independence. By the time this guerrilla war between the IRA and British crown forces began, the Fianna were well prepared to serve the republican cause and not just as a training ground for future IRA members. In Cork, for instance, Fianna boys not only volunteered as scouts and dispatch carriers for the IRA, but also raided private homes for arms, destroyed the stores of crown forces, and attacked individuals whom they deemed 'enemy personnel' (Meaney, 1957). The targets of such activities probably viewed the boys as juvenile delinquents rather than young freedom fighters. Even members of the IRA occasionally expressed disquiet about the Fianna's activities. A representative of the North Louth Battalion wrote to the IRA's headquarters in Dublin on 3 July 1920 complaining about the impact of the Dundalk Fianna's independent arms raids on the local community. The dangers of overlapping arms raids were among the issues that finally led to the forging of 
an official link between the Fianna and the IRA in early 1921 to facilitate cooperation and a degree of control on the part of the IRA.

\section{Conclusion}

The establishment of the Fianna was an Irish nationalist manifestation of the uniformed 'pseudo-military' youth group, one example of children's culture produced by the anxieties associated with the approaching war, though the war for which the Fianna were preparing in the years between 1909 and 1918 was not the First World War, but the Irish War of Independence. Among the outcomes of this guerrilla war was the negotiation of the 1921 Anglo-Irish Treaty that granted Dominion status to the twenty-six southern counties that would comprise the Irish Free State, now the modern Republic of Ireland. Although established as a mode of indoctrinating and mobilizing youth as a potential resource for the adult advanced nationalist movement, the Fianna also empowered members, enabling them to develop new skills, gain hands-on experience, and ultimately help to shape their nation's destiny. [p. 279]

\section{Bibliography}

Anon. (1909) 'Fianna Éireann'. An Claidheamh Soluis, 21 August, p. 10.

Anon. (1922) Easter Week 1916-1922 Commemoration Aeridheacht Souvenir Programme. Dublin: Fianna Éireann Dublin Brigade.

Anon. (1929) Fianna Code of Honour, National Library of Ireland, MS 10,910.

Baden-Powell, R.S.S. (1908) Scouting for Boys: A Handbook for Instruction in Good Citizenship. $5^{\text {th }}$ Impression. London: C. Arthur Pearson.

Bevan, Séamas (1955), WS 1058, 7 January. Bureau of Military History witness statements, Military Archives, Dublin. 
Ceannt, Áine (1949) WS 264, 27 May. Bureau of Military History witness statements, Military Archives, Dublin.

County Inspectors Confidential Reports (1917) The National Archives, Kew, CO 904/103, June.

de Markievicz, Constance (1923) 'Memories', Éire, 18 August, p. 5.

Donson, Andrew (2006) 'Why did German Youth Become Fascists? Nationalist Males Born 1900 to 1908 in War and Revolution'. Social History, 31(3): 337-358.

---. (2010) Youth in the Fatherless Land: War Pedagogy, Nationalism and Authority in Germany, 1914-1918. Cambridge, MA: Harvard University Press.

Duggan, Peg (1957) WS 1576, 14 February. Bureau of Military History witness statements, Military Archives, Dublin.

'Fianna Roll of Honour' (circa 1981). In: Robert Holland, A Short History of Fianna Éireann. National Library of Ireland, MS 35,455/3/12A, pp. 25-6.

Fitzpatrick, David (1996) 'Militarism in Ireland, 1900-1922'. In: Thomas Bartlett and Keith Jeffery (eds) A Military History of Ireland. Cambridge: Cambridge University Press, pp. 379-406.

Fulham, James (1952) WS 630, 3 January. Bureau of Military History witness statements, Military Archives, Dublin.

Gaughan, J. Anthony (2006) Scouting in Ireland. Dublin: Kingdom Books.

Hay, Marnie (2008) 'The Foundation and Development of Na Fianna Éireann, 1909-16'. Irish Historical Studies, 36(141): 53-71.

---. (2009) Bulmer Hobson and the Nationalist Movement in Twentieth-Century Ireland.

Manchester: Manchester University Press.

---. (2011), 'Moulding the Future: Na Fianna Éireann and its Members, 1909-23'. Studies: an Irish quarterly review, 100(400): 441-54. 
Hearne, Patrick (1958) WS 1742, 18 August. Bureau of Military History witness statements, Military Archives, Dublin.

Heron (née Connolly), Ina (1954) WS 919, 25 January. Bureau of Military History witness statements, Military Archives, Dublin.

Heywood, Colin (2005) A History of Childhood. Cambridge: Polity.

Hobson, Bulmer (1968) Ireland Yesterday and Tomorrow. Tralee: Anvil Books. [p. 280]

Irish Girl Guides (2009) 'History of Irish Girl Guides'. Available at:

http//www.irishgirlguides.ie/index.php/history-of-irish-girl-guides (accessed 14 May 2014).

Jacob, Rosamond (1916) Diary Entry. National Library of Ireland, Rosamond Jacob Papers, MS 32,582 (30), 6 July, 10 October.

Kavanagh, Séamus (1957) WS 1670, 9 September. Bureau of Military History witness statements, Military Archives, Dublin.

Kennedy, Seán (1953) WS 842, 1 May. Bureau of Military History witness statements, Military Archives, Dublin.

Lane, Leeann (2010) Rosamond Jacob: Third Person Singular. Dublin: UCD Press.

Langley, Liam (1953) WS 816, 19 March. Bureau of Military History witness statements, Military Archives, Dublin.

Lonergan, Michael (1948) WS 140, 1 August. Bureau of Military History witness statements, Military Archives, Dublin.

MacCaisin, Seumas (1947), WS 8, 8 June. Bureau of Military History witness statements, Military Archives, Dublin.

Mac Fhloinn, Pádraig (1988) ‘The History and Tradition of Fianna Éireann'. In: Fianna Éireann Handbook. Dublin, Fianna Éireann, pp 7-21. 
Martin, Eamon (1951) WS 591, 1 October. Bureau of Military History witness statements, Military Archives, Dublin.

Marreco, Anne (1967) The Rebel Countess. London: Weidenfeld and Nicolson.

Matthews, Ann (2010) Renegades: Irish Republican Women, 1900-1922. Cork: Mercier. McCabe, William (Liam) (1955) WS 1212, 25 July. Bureau of Military History witness statements, Military Archives, Dublin.

McLoughlin, Mary (1954) WS 934, circa February. Bureau of Military History witness statements, Military Archives, Dublin.

McNeill, Hugo (1956) WS 1377, 20 March. Bureau of Military History witness statements, Military Archives, Dublin.

Meaney, Charles (1957) WS 1631, 11 June. Bureau of Military History witness statements, Military Archives, Dublin.

Mellows, Liam (1917) 'The Irish Boy Scouts by an Irish Volunteer officer, Chapter IV', Military Archives, Dublin, Bureau of Military History, Col. Dan Bryan Collection, CD 129/1.

Morris, Brian (1970), 'Ernest Thompson Seton and the Origins of the Woodcraft Movement'. Journal of Contemporary History, 5(2): 183-194.

Nelson, Willie [Ó Riain, Pádraic] (1915) 'Na Fiann Éireann'. Irish Volunteer, 13 February, p. 8.

---. (1915) ‘Na Fianna Éireann’. Irish Volunteer, 13 March, p. 8.

---. (1915) 'Na Fianna Éireann'. Irish Volunteer, 17 April, p. 8.

---. (1915a) ‘Na Fianna Éireann’, Irish Volunteer, 26 June, p. 8.

North Louth Battalion IRA to Adjutant General (1920) Military Archives, Dublin, Collins Collection, A/0472/27, 3 July. 
Novick, Ben (2001) Conceiving Revolution: Irish Nationalist Propaganda During the First World War. Dublin: Four Courts.

O’Callaghan, Liam (1947) WS 47, 4 October. Bureau of Military History witness statements, Military Archives, Dublin.

O’Donoghue, Fr Thomas (n.d.) WS 1666. Bureau of Military History witness statements, Military Archives, Dublin. [p. 281]

O’Regan, Martin (1955) WS 1202, 29 June. Bureau of Military History witness statements, Military Archives, Dublin.

Ó Riain, Pádraic (ed.) (1914) Fianna Handbook. Dublin: Central Council of Na Fianna Éireann.

[Ó Riain, Pádraic?] (1913) ‘Na Fianna Éireann’. Irish Freedom, January, p. 6.

---. (1914) ‘National Boy Scouts’. Irish Volunteer, 14 November, p. 16.

---. (1914) ‘National Boy Scouts’. Irish Volunteer, 28 November, p. 15.

---. (1915) 'Na Fianna Éireann'. Irish Volunteer, 12 June, p. 8.

Ó Ruairc, Pádraig Óg (2013) ‘A Short History of the Hibernian Rifles, 1912-1916’, 31 March. Available at: http//www.theirishstory.com/2013/03/31/a-short-history-of-thehibernian-rifles-1912-1916/\#.UjHVCNKOSuI (accessed 14 August 2013).

O’Shea, Joseph (n.d.) WS 21. Bureau of Military History witness statements, Military Archives, Dublin.

Paŝeta, Senia (2009) 'Markievicz, Constance Georgine'. In: James McGuire and James Quinn (eds), Dictionary of Irish Biography. Cambridge: Cambridge University Press (accessed 23 November 2012).

Pearse, P.H. (1914) 'The Fianna of Fionn’. In: [Ó Riain, Pádraic (ed.)] Fianna Handbook . Dublin: Central Council of Na Fianna Éireann, pp. 151-165. 
Reader, Séamus (1951) WS 627, 28 December. Bureau of Military History witness statements, Military Archives, Dublin.

Smith, Robert A. (1997a) 'Boys' Brigade'. In: John Cannon (ed.), The Oxford Companion to British History. Oxford: Oxford University Press, p. 119.

---. (1997b) 'Boy Scouts’. In: John Cannon (ed.), The Oxford Companion to British History. Oxford: Oxford University Press, p. 119.

Springhall, John (1986) Coming of Age: Adolescence in Britain, 1860-1960. Dublin: Gill and Macmillan.

---. (1987) 'Baden-Powell and the Scout Movement Before 1920: Citizen Training or Soldiers of the Future?' English Historical Review, 102(405): 934-42.

Warren, Allen (1986) 'Sir Robert Baden-Powell, the Scout Movement and Citizen Training in Great Britain, 1900-1920’. English Historical Review, 101(399): 376-98.

Weekly Irish Times (1917) Sinn Féin Rebellion Handbook, Easter 1916. Dublin: Irish Times. William White, Lawrence (2009) 'Hogan (Dilloughery), Austin’. In: James McGuire and James Quinn (eds), Dictionary of Irish Biography. Cambridge: Cambridge University Press (accessed 7 February 2011). [p. 282]

\section{Notes}

\footnotetext{
${ }^{1}$ Individuals who advocated a greater degree of independence for Ireland than mere home rule are known as advanced nationalists.

${ }^{2}$ In some contemporary documents, the organization's name is spelled Clan na Gael and its members called Girl Guides.

${ }^{3}$ Others have suggested that the split in the Fianna was actually over hat design (Bevan, 1955;

O’Regan, 1955; Kennedy, 1953). [p. 280]
} 